\author{
G.S. Tasbulatova ${ }^{1}$, A.U. Umbetov ${ }^{2}$, B.S. Sadykova ${ }^{2}$ \\ ${ }^{1}$ L.N. Gumilyov Eurasian National University, Nur-Sultan, Kazakhstan; \\ ${ }^{2}$ Y. Altynsarin Arkalyk State Pedagogical Institute, Kazakhstan \\ (E-mail: gulim55@mail.ru)
}

\title{
Indicators of the cardiovascular system of 7-11 years old girls residing in Northern and Southern Kazakhstan
}

\begin{abstract}
Functional characteristics are the leading criterion for assessing the health status of school students'. The body of a schoolchild in its aforementioned signs differs from the body of an adult. Schoolchildren are more sensitive to environmental factors. Physical condition may depend on age, gender, and location. The indicators of the cardiovascular system (CVS) of girls in the ontogenesis of 7-11 years in the city of Pavlodar and Kyzylorda were studied. In the article the results of a study of such indicators as heart rate (HR), systolic and diastolic blood pressure (SBP, DBP) are presented. Based on these data, pulse pressure (PP), double product (DP), reflecting the cost-effectiveness of the cardiovascular system, systolic blood volume (SBV) and minute blood volume (MBV), an indicator of blood circulation efficiency (BCE); Kerdo's vegetative index (KVI), reflecting the vegetative balance are calculated. The adaptation mechanisms and features of the reaction of the cardiovascular system to physical activity are revealed. Under the conditions of performing standard steregometric physical activity, heart rate (HR), double product (DP) of girls have significantly increased compared with the state of rest.
\end{abstract}

Keywords: cardiovascular system, physical activity, circulatory efficiency, functional indicators of the body, reserves.

\section{Introduction}

The functional features of primary school children, depending on the climatic and geographical conditions of the Kyzylorda city of the southern region of the Republic of Kazakhstan, have been studied little. A functional features of younger schoolchildren in the northern and southern region in a comparative aspect was not carried out.

In connection with the foregoing, the study of functional features of the organism of schoolchildren in Northern and Southern Kazakhstan seems relevant.

The cardiovascular system is a sensitive indicator of all processes occurring in the body, as it is responsible for the integration of all components of the body into a single integral system. It participates in almost any adaptation process of the body as an integral part of a holistic physiological reaction [1].

The purpose of the study is to study the indicators of the cardiovascular system of 7-11 years old girls living in the city of Pavlodar and Kyzylorda.

As a result of the studies, functional features were first revealed with schoolchildren of 7-11 years old, living in Kyzylorda.

\section{Materials and research methods}

To achieve this goal, 100 girls of the Pavlodar comprehensive school № 22 and Kyzylorda comprehensive school № 7 aged 7-11 years old were examined, 20 girls in each age group. All examined children for health status reasons belonged to the main medical group. Surveys were carried out in the morning.

Measurements of the indicators of the cardiovascular system were carried out according to the method of step ergometry in the form of a 2-step Harvard test with a step height of $20 \mathrm{~cm}$.

Heart rate was determined by using an electrocardiograph. Blood pressure was measured by the Korotkov auscultation method, followed by a pulse pressure calculation.

Calculation of systolic blood volume was carried out according to the Starr formula SBV $=40+$ $+0,5 \mathrm{PD}-0,6 \mathrm{DBP}+3,2 \mathrm{~A}$, : where $\mathrm{A}$ is age in years.

For an integral assessment of the state of the circulatory apparatus, the minute volume of blood (MVB) was calculated with following the formula: $\mathrm{MVB}=\mathrm{SBV} \times \mathrm{HR}$.

The Kerdo Vegetative Index, which reflects the balance of vegetative processes under adaptation, was calculated with the formula: KVI $=(1-\mathrm{DBP} / \mathrm{HR}) \times 100$. 
Blood circulation efficiency $(\mathrm{BCE})$ index was calculated with the formula: $\mathrm{BCE}=(\mathrm{SBP} / \mathrm{HR}) \times 100[2]$. This indicator judges the quality of the response of the cardio-respiratory system to stress.

The cost-effectiveness of the cardiovascular system when performing standard stepergometric load was estimated by the double product (DP), equal to the product of the heart rate and systolic blood pressure [3].

The results were calculated using methods of mathematical statistics based on arithmetic (M) means and their errors $( \pm \mathrm{m})$.

\section{The results of the study and discussion}

In the study of the cardiovascular system in schoolgirls Pavlodar compared with schoolgirls Kyzylorda found high values of heart rate (Tables 1,2 ).

Significant differences between peers of different regions were found in the study of SBP and DBP. As follows from the data presented in table 1 and 2, the girls of Pavlodar had high values of SBP and DBP both at rest and in load. Indicators of DP at girls of Pavlodar in the conditions of rest and loading are significantly higher than in comparison with pupils of Kyzylorda at the age of 7-11 years. This indicated an increase in the physiological cost of physical activity in these girls. Indicators of SBV, MBV are higher in schoolgirls of Kyzylorda compared to peers of Pavlodar, both at rest and load.

$\mathrm{Table} 1$

Indicators of the cardiovascular system at the state of rest of 7-11 years old girls living the city of Pavlodar (P) and Kyzylorda (K)

\begin{tabular}{|c|c|c|c|c|c|c|}
\hline \multirow{2}{*}{ Parameters } & \multirow{2}{*}{ Residence } & \multicolumn{5}{|c|}{ Age, years } \\
\hline & & 7 & 8 & 9 & 10 & 11 \\
\hline \multirow{2}{*}{$\begin{array}{l}\text { Number } \\
\text { of examined }\end{array}$} & $\mathrm{P}$ & $n=20$ & $n=20$ & $n=20$ & $n=21$ & $n=20$ \\
\hline & $\mathrm{K}$ & $n=20$ & $n=20$ & $n=20$ & $n=20$ & $n=20$ \\
\hline \multirow{2}{*}{$\mathrm{HR}$, beats/ min } & $\mathrm{P}$ & $95.7 \pm 0.3$ & $95.1 \pm 0.6$ & $94.0 \pm 0.5$ & $92.0 \pm 1.0^{*}$ & $90.1 \pm 1.0$ \\
\hline & $\mathrm{K}$ & $93.8 \pm 0.4 \#$ & $93.2 \pm 0.3 \#$ & $90.9 \pm 0.5^{*} \#$ & $89.1 \pm 0.9 \#$ & $88.8 \pm 1.0$ \\
\hline \multirow{2}{*}{$\mathrm{SBP}, \mathrm{mmHg}$} & $\mathrm{P}$ & $94.5 \pm 1.1$ & $95.5 \pm 1.1$ & $97.0 \pm 1.3$ & $99.0 \pm 1.4$ & $102.0 \pm 1.7$ \\
\hline & $\mathrm{K}$ & $90.0 \pm 1.0 \#$ & $92.0 \pm 0.9 \#$ & $95.0 \pm 1.1^{*}$ & $97.0 \pm 1.1$ & $97.5 \pm 1.0 \#$ \\
\hline \multirow{2}{*}{$\mathrm{DBP}, \mathrm{mmHg}$} & $\mathrm{P}$ & $60.5 \pm 1.5$ & $61.0 \pm 1.4$ & $61.0 \pm 1.0$ & $61.4 \pm 1.0$ & $62.5 \pm 1.6$ \\
\hline & $\mathrm{K}$ & $52.5 \pm 1.0 \#$ & $53.0 \pm 1.1 \#$ & $55.5 \pm 1.1 \#$ & $56.5 \pm 1.1 \#$ & $56.5 \pm 1.1 \#$ \\
\hline \multirow{2}{*}{$\mathrm{PP}, \mathrm{mmHg}$} & $\mathrm{P}$ & $34.0 \pm 1.1$ & $35.5 \pm 1.4$ & $36.0 \pm 1.1$ & $37.6 \pm 1.2$ & $39.5 \pm 0.5$ \\
\hline & $\mathrm{K}$ & $37.5 \pm 1.0 \#$ & $39.0 \pm 0.7 \#$ & $39.5 \pm 0.9 \#$ & $40.5 \pm 0.5 \#$ & $41.0 \pm 0.7$ \\
\hline \multirow{2}{*}{ DP, y.e. } & $\mathrm{P}$ & $90.4 \pm 1.0$ & $90.8 \pm 1.1$ & $91.2 \pm 1.5$ & $91.2 \pm 1.5$ & $91.8 \pm 1.4$ \\
\hline & $\mathrm{K}$ & $84.4 \pm 0.9 \#$ & $85.8 \pm 1.0 \#$ & $86.3 \pm 1.1 \#$ & $86.4 \pm 1.4 \#$ & $86.6 \pm 1.2 \#$ \\
\hline \multirow{2}{*}{$\mathrm{SBV}, \mathrm{ml}$} & $\mathrm{P}$ & $43.1 \pm 1.4$ & $47.4 \pm 1.3^{*}$ & $50.2 \pm 0.9$ & $54.0 \pm 1.0 *$ & $57.5 \pm 1.0 *$ \\
\hline & $\mathrm{K}$ & $49.7 \pm 0.9 \#$ & $53.3 \pm 0.9 * \#$ & $55.3 \pm 0.9 \#$ & $58.4 \pm 0.8^{* \#}$ & $61.8 \pm 0.9 * \#$ \\
\hline \multirow{2}{*}{$\mathrm{MBV}, \mathrm{ml}$} & $\mathrm{P}$ & $4.12 \pm 0.1$ & $4.50 \pm 0.1^{*}$ & $4.72 \pm 0.1$ & $4.97 \pm 0.1$ & $5.18 \pm 0.1$ \\
\hline & $\mathrm{K}$ & $4.66 \pm 0.1 \#$ & $4.97 \pm 0.1$ *\# & $5.09 \pm 0.1 \#$ & $5.19 \pm 0.1$ & $5.49 \pm 0.1 * \#$ \\
\hline \multirow{2}{*}{ KVI, cond. units } & $\mathrm{P}$ & $0.37 \pm 0.02$ & $0.37 \pm 0.01$ & $0.35 \pm 0.01$ & $0.33 \pm 0.02$ & $0.30 \pm 0.02$ \\
\hline & $\mathrm{K}$ & $0.44 \pm 0.01 \#$ & $0.43 \pm 0.01 \#$ & $0.39 \pm 0.01 * \#$ & $0.36 \pm 0.01$ & $0.36 \pm 0.01 \#$ \\
\hline \multirow{2}{*}{$\mathrm{BCE}$} & $\mathrm{P}$ & $98.9 \pm 1.4$ & $100.5 \pm 1.5$ & $103.2 \pm 1.2$ & $108.2 \pm 2.0 *$ & $113.6 \pm 2.7$ \\
\hline & $\mathrm{K}$ & $96.0 \pm 1.3$ & $98.7 \pm 0.9$ & $104.6 \pm 1.4^{*}$ & $109.1 \pm 1.6^{*}$ & $110.1 \pm 1.7$ \\
\hline
\end{tabular}

Notes. Reliability of the difference in mean values for nonparametric independent samples: * — relative to the previous age group $(P<0.05)$; \# - when comparing schoolgirls living in the Northern and Southern regions $(P<0.05)$.

In a state of relative rest during individual development, a decrease in heart rate from $93.8 \pm 0.4$ for 7 years old girls of Kyzylorda to $88.8 \pm 1.0$ beats/min for 11 years old girls was observed (Table 1 ).

The values of SBP, DBP, PD from 7 to 11 years old girls of Kyzylorda have steadily increased.

An indicator of the state of the reserves of the cardiovascular system is the «double product», which characterizes the systolic function of the heart. The lower the DP at the state of rest, the higher the maximum aerobic capacity and, consequently, the level of somatic health of the individual [5].

Vegetative Index Kerdo (VIK) in conditions of relative rest girls of Kyzylorda tends to decrease from $0.44 \pm 0.01$ for 7 years old girls to $0.36 \pm 0.01$ for 11 years old girls, as a result of a decrease in the tone of the sympathetic nervous system. Indicators BCE tended to increase with ageing. 
Table 2 shows indicators of the response of the cardiovascular system to physical activity at different age periods.

Table 2

Indicators of the cardiovascular system of 7-11 years old girls living in the city of Pavlodar (P) and Kyzylorda (K) under standard steregometric physical activity

\begin{tabular}{|c|c|c|c|c|c|c|}
\hline \multirow{2}{*}{ Parameters } & \multirow{2}{*}{ Residence } & \multicolumn{5}{|c|}{ Age, years } \\
\hline & & 7 & 8 & 9 & 10 & 11 \\
\hline \multirow{2}{*}{$\begin{array}{l}\text { Number } \\
\text { of examined }\end{array}$} & $\mathrm{P}$ & $n=20$ & $n=20$ & $n=20$ & $n=21$ & $n=20$ \\
\hline & $\mathrm{K}$ & $n=20$ & $n=20$ & $n=20$ & $n=20$ & $n=20$ \\
\hline \multirow{2}{*}{$\mathrm{HR}$, beats/min } & $\mathrm{P}$ & $170.1 \pm 0.5$ & $169.2 \pm 0.5$ & $168.0 \pm 0.5$ & $166.6 \pm 0.5$ & $166.2 \pm 0.6$ \\
\hline & $\mathrm{K}$ & $154.8 \pm 0.5 \#$ & $154.2 \pm 0.5 \#$ & $153.1 \pm 0.4 \#$ & $152.7 \pm 0.5 \#$ & $152.3 \pm 0.6 \#$ \\
\hline \multirow{2}{*}{$\mathrm{SBP}, \mathrm{mmHg}$} & $\mathrm{P}$ & $128.0 \pm 1.2$ & $129.5 \pm 1.4$ & $132.0 \pm 1.4$ & $135.7 \pm 1.6$ & $138.0 \pm 1.6$ \\
\hline & $\mathrm{K}$ & $124.0 \pm 1.3 \#$ & $125.5 \pm 1.1 \#$ & $129.5 \pm 1.1^{*}$ & $131.0 \pm 1.6 \#$ & $136.5 \pm 1.3 * \#$ \\
\hline \multirow{2}{*}{$\mathrm{DBP}, \mathrm{mmHg}$} & $\mathrm{P}$ & $62.5 \pm 1.6$ & $62.5 \pm 1.0$ & $63.0 \pm 1.1$ & $63.3 \pm 1.3$ & $63.5 \pm 1.3$ \\
\hline & $\mathrm{K}$ & $54.0 \pm 1.1 \#$ & $54.5 \pm 1.1 \#$ & $55.5 \pm 1.1 \#$ & $56.5 \pm 1.1 \#$ & $57.0 \pm 1.1 \#$ \\
\hline \multirow{2}{*}{$\mathrm{PP}, \mathrm{mmHg}$} & $\mathrm{P}$ & $65.8 \pm 1.8$ & $67.0 \pm 1.5$ & $69.0 \pm 1.6$ & $72.4 \pm 1.7$ & $74.5 \pm 1.1$ \\
\hline & $\mathrm{K}$ & $70.0 \pm 1.5$ & $71.0 \pm 1.6$ & $74.0 \pm 1.3 \#$ & $74.5 \pm 1.4$ & $79.5 \pm 1.5^{*} \#$ \\
\hline \multirow{2}{*}{ DP, y.e. } & $\mathrm{P}$ & $217.4 \pm 2.0$ & $219.1 \pm 2.4$ & $221.7 \pm 2.6$ & $226.1 \pm 2.9$ & $229.3 \pm 2.5$ \\
\hline & $\mathrm{K}$ & $191.9 \pm 2.2 \#$ & $193.5 \pm 2.0 \#$ & $198.2 \pm 1.8 \#$ & $200.1 \pm 2.6 \#$ & $207.9 \pm 2.1 * \#$ \\
\hline \multirow{2}{*}{$\mathrm{SBV}, \mathrm{ml}$} & $\mathrm{P}$ & $57.7 \pm 1.8$ & $61.6 \pm 1.1$ & $65.5 \pm 1.3^{*}$ & $70.2 \pm 1.3 *$ & $74.4 \pm 1.1 *$ \\
\hline & $\mathrm{K}$ & $65.0 \pm 1.2 \#$ & $68.4 \pm 1.4 \#$ & $72.5 \pm 1.2 * \#$ & $75.4 \pm 1.2 \#$ & $80.8 \pm 1.2 * \#$ \\
\hline \multirow{2}{*}{$\mathrm{MBV}, \mathrm{ml}$} & $\mathrm{P}$ & $9.8 \pm 0.3$ & $10.4 \pm 0.2$ & $11.0 \pm 0.2^{*}$ & $11.7 \pm 0.2^{*}$ & $12.4 \pm 0.2 *$ \\
\hline & $\mathrm{K}$ & $10.1 \pm 0.2$ & $10.6 \pm 0.2$ & $11.1 \pm 0.2$ & $11.5 \pm 0.2$ & $12.3 \pm 0.2 *$ \\
\hline \multirow{2}{*}{ KVI, cond. units } & $\mathrm{P}$ & $0.63 \pm 0.01$ & $0.63 \pm 0.01$ & $0.62 \pm 0.01 *$ & $0.62 \pm 0.01$ & $0.62 \pm 0.01$ \\
\hline & $\mathrm{K}$ & $0.65 \pm 0.01 \#$ & $0.65 \pm 0.01 \#$ & $0.64 \pm 0.01 * \#$ & $0.63 \pm 0.01 * \#$ & $0.63 \pm 0.01 \#$ \\
\hline \multirow{2}{*}{$\mathrm{BCE}$} & $\mathrm{P}$ & $75.3 \pm 0.7$ & $76.6 \pm 0.8$ & $78.6 \pm 0.8$ & $81.5 \pm 1.0 *$ & $83.1 \pm 1.0$ \\
\hline & $\mathrm{K}$ & $80.1 \pm 0.9 \#$ & $81.4 \pm 0.7 \#$ & $84.6 \pm 0.8 * \#$ & $85.8 \pm 1.0 \#$ & $89.7 \pm 0.9 * \#$ \\
\hline
\end{tabular}

Notes. Reliability of the difference in mean values for nonparametric independent samples: * - relative to the previous age group $(P<0.05)$; \# - when comparing schoolgirls living in the Northern and Southern regions $(P<0.05)$.

As you can see, the implementation of standard stepergometric physical activity of girls of Kyzylorda was accompanied by a significant increase in heart rate (HR) and double product (DP) when compared with the state of rest. The values of systolic (SBP), diastolic(DBP), and pulse pressure (PD) tended to increase with ageing. Systolic blood volume and minute blood volume of girls under studies have increased during ontogenesis. The increase in MVB from 7 to 11 years old period is caused by an increase in stroke volume of blood, since heart rate decreases in this age period. Indicators of the Kerdo Vegetative Index allows us to conclude that, in schoolgirls it decreases with aging. In general, for girls BCE increases with age. Also, for the studied period indicators of BCE increased by 9.6 c.u.

\section{Conclusions}

In terms of compliance steregometric physical activity have significantly increased the indicators HR, CBP, DBP, PP, DP, SBV, MBV, KVI compared to the rest. BCE decreased significantly compared to rest.

\section{References}

1 Баевский Р.М. Математический анализ изменений сердечного ритма при стрессе / Р.М. Баевский. — M.: Наука, 1984. $-226 \mathrm{c}$.

2 Айзман Р.И. Методика комплексной оценки здоровья учащихся общеобразовательных школ / Р.И. Айзман, Н.И. Айзман, А.В. Лебедев, В.Б. Рубанович. - Новосибирск, 2008. - 77 с.

3 Чурин В.Д. О хроноинотропном резерве миокарда / В.Д. Чурин // Физиология человека. — 1978. — Т. 4, № 3. C. 394-395.

4 Лакин Г.Ф. Биометрия: учеб. пос. для биол. спец. вузов. - 3-е изд., перераб. и доп. / Г.Ф. Лакин. - М.: Высш. шк., 1980. $-293 \mathrm{c}$.

5 Апанасенко Г.Л. Медицинская валеология / Г.Л. Апанасенко, Л.А. Попова. — Ростов н/Д.: Феникс, 2000. - 248 с. 


\title{
Г.С. Тасбулатова, А.У. Умбетов, Б.С. Садыкова \\ Қызылорда қаласындағы 7-11 жастағы қыз балалардың жүрек қантамыр жүйесінің көрсеткіштері
}

\begin{abstract}
Функционалдық сипаттамалар оқушылардың денсаулық жағдайын бағалаудың басты өлшемі болып табылады. Окушы ағзасы жоғарыда аталған белгілер бойынша ересек адамның ағзасынан ерекшеленеді. Оқушылар сыртқы орта факторларға аса сезімтал. Физикалық жағдай жасына, жынысына және тұратын жеріне байланысты болуы мүмкін. Павлодар және Қызылорда қаласының 711 жас аралығындағы онтогенездегі қыздардың жүрек-қантамыр жүйесінің (ЖҚЖ) көрсеткіштері зерттелген. Мақалада жүрек соғу жиілігі (ЖСЖ), систолалық және диастолалық артериалды қысым (САҚ, ДАҚ) сияқты көрсеткіштерді зерттеу нәтижелері келтірілген. Осы мәліметтер негізінде пульстық қысымның, жүрек-қан тамыр жүйесінің (ЖҚТ) қызметінің тиімділігін, систолалық қан көлемінің (СҚК) мен минуттық қан көлемінің (МҚК), қан айналымы тиімділігінің көрсеткішін (ҚТК), вегетативті тепе-теңдікті анықтайтын Кердо вегетативті индексін (КВИ) көрсететін қосарлы өнім есептелген. Бейімделу механизмдері мен жүрек-қантамыр жүйесінің физикалық белсенділікке реакциясының ерекшеліктері анықталған. Степэргометриялық жүктемені орындау кезінде ЖЖЖ, САҚ, ДАҚ, ПҚ, ҚӨ, СҚК, ДҚК, КВИ тыныштық күйдегі көрсеткіштерімен салыстырғанда едәуір артты. КТК көрсеткіші айтарлықтай төмендеді.
\end{abstract}

Кілт сөздер: жүрек-қантамыр жүйесі, физикалық жүктеме, қан айналымның тиімділігі, ағзаның функционалды көрсеткіштері, қоры.

\section{Г.С. Тасбулатова, А.У. Умбетов, Б.С. Садыкова}

\section{Показатели сердечно-сосудистой системы девочек 7-11 лет г. Кызылорды}

\begin{abstract}
Функциональные характеристики являются ведущим критерием оценки состояния здоровья школьников. Организм школьника по своим упомянутым выше признакам отличается от организма взрослого человека. Школьники более чувствительны к факторам внешней среды. Физическое состояние может зависеть от возраста, пола и места проживания. Изучены показатели сердечно-сосудистой системы (CCC) девочек в онтогенезе 7-11 лет гг. Павлодара и Кызылорды. В статье приведены результаты исследования таких показателей, как частота сердечных сокращений (ЧСС), систолическое и диастолическое артериальное давление (САД, ДАД). На основании этих данных проводился расчет пульсового давления (ПД), двойного произведения (ДП), отражающего экономичность деятельности сердечнососудистой системы, систолический объем крови (СОК) и минутный объем крови (МОК), показатель эффективности кровообращения (ПЭК), вегетативный индекс Кердо (ВИК), определяющий вегетативный баланс. Выявлены механизмы адаптации и особенности реакции сердечно-сосудистой системы на физическую нагрузку. В условиях выполнения степэргометрической нагрузки значительно возросли показатели ЧСС, САД, ДАД, ПД, ДП, СОК, МОК, ВИК. ПЭК значительно уменьшились по сравнению с покоем.
\end{abstract}

Ключевые слова: сердечно-сосудистая система, физическая нагрузка, эффективность кровообращения, функциональные показатели организма, резервы.

\section{References}

1 Baevsky, R.M. (1984). Matematicheskii analiz izmenenii serdechnoho ritma pri stresse [Mathematical analysis of changes in heart rate during stress]. Moscow [in Russian].

2 Ayzman, R.I., Ayzman, N.I., Lebedev, A.V., \& Rubanovich, V.B. (2008). Metodika kompleksnoi otsenki zdorovia uchashchikhsia obshcheobrazovatelnykh shkol [Methodology for the comprehensive assessment of the health of students in secondary schools]. Novosibirsk [in Russian].

3 Churin, V.D. (1978). O khronoinotropnom rezerve miokarda [About chronoinotropic myocardial reserve]. Fiziolohiia cheloveka - Human physiology, 4, 3, 394-395 [in Russian].

4 Lakin, G.F. (1980). Biometriia [Biometrics]. (3rd ed., Revised. and add.). Moscow: Vysshaia shkola [in Russian].

5 Apanasenko, G.L., Apanasenko, G.L., \& Popova, L.A. (2000). Meditsinskaia valeolohiia [Medical Valeology]. Rostov on Don: Phoenix [in Russian]. 